\title{
空中马真測量の解析標定と機械罒化の嗃矢
}

一一本氏房先生藍綬賲章受賞を祝して——

坂野久重郎*

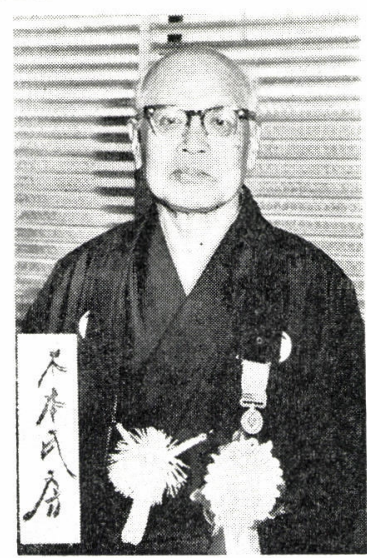

\section{Congratulation to Mr. Ujifusa Kimoto, a pioneer of analitical and analogical Photogrammetry in Japan}

by K. Sakano,

\begin{abstract}
Recently he was awarded a Blue Ribbon Medal by the Government in recognition of his brilliant activities in the photogrammetric works in Japan.

I remember that:

In 1921, Japan came into possession of a Hugerschoff's Autocartograph, and in 1922 , Mr. Ujifusa Kimoto put into practice the photogrammetry in Japan with this plotter.

Since then he devoted his entire career to the delopment of the photogrammetry in our country.
\end{abstract}

\section{1. 空中写真測量の黎明}

写真の発明と殆んど同時に初められた測板式の写真 測量は 1901 年 Purflich によって人間の立体視感機 能が導入され，これを基礎として 1909 年 Orel によ って地上写真測量用の Stereoautograph また, 1915 年, Gasser によって垂直空中写真測量用の二重投影 機そして, 1920 年 Hugerschoff によって一般解法の 空中写真測量用として Autocartograph が作られた。 これは今日われわれが用いている図化機の基礎となっ ている最初の機械であった。

この Hugerschoff の Autocartograph が 1921 年 （大正 10 年）第一次大戦の賠償物資としてわが国に むたせられ，わが木本氏房先生等によってその研究が 行なわれ，所沢地区を気球写真から図化したのは今か ら 40 年前の 1922 年 (大正 11 年) のことであった。 これがわが国で行なわれた初めての空中写真測量であ って，座標测定機（コンパレータ）によって写真座標 を測定し，計算によって標定を行なったもので，今日 われわれが解析法と称している才法の㜴矢でもあっ て，電子計算機もない当時には数多くの困難があった
わけである。

ここに木本氏房先生の藍綬袈章受賞を祝して, 残っ ている当時の貴重な資料と記憶をたどりつつ，その大 要を記す次第である。

\section{2. 気球による空中写真の撮影}

撮影力メラは次の性能を有する Heyde の手持空中 写真機圭用いた。

焦点距離 $16.5 \mathrm{~cm}$, 口径比 F/12.5

乾板の大さ $13 \times 18 \mathrm{~cm}$

第 1 図はそのカメラで，その内部標定を地上で基準 点を水平に撮影して Hugerschoff-Cranz 法11によって 点検した結果は次の通りであった。

$f_{x}=165.62 \pm 0.03 \mathrm{~mm} \quad x_{0}=1.44 \pm 0.11 \mathrm{~mm}$

$f_{y}=165.52 \pm 0.05 \mathrm{~mm} \quad y_{0}=0.83 \pm 0.19 \mathrm{~mm}$

第 2 図はその結果から求めたディストーション曲線 である。

試験作業として所沢地区において，撮影基線約 1,000 m, 高度約 $400 \mathrm{~m}$ の撃留気球から基線にほぼ直 角, 俯角約 $30^{\circ}$ で撮影を行なった。

第 3 図はその左写真である。

\section{* 国際航業怢式会社研究室}




\section{3. 標定計算}

外部標定のための写真座標測定には第 4 図に示す如 き精度 $0.01 \mathrm{~mm}$ の夾標測定機 (単眼コンパレータ) を, 刻点には第 5 図に示す如き標刻器を用い，また投 影中心原点とする写真像点の立体角の測定には影像 測定経緯儀（Goniometer）を用いた。

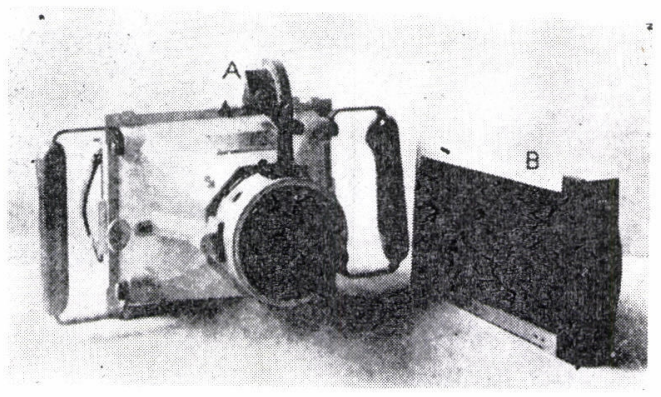

第 1 図手持空中肎真機

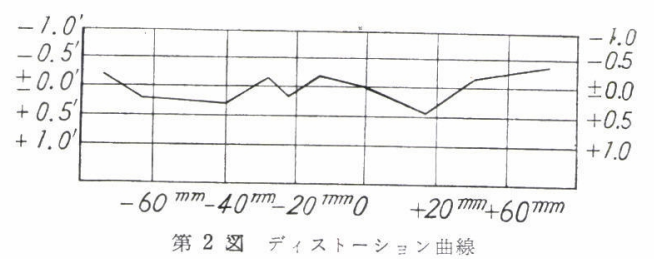

これらの機械によって測定した諸元と, 地上図根点 とのデータとを用いて，まず撮影点と三つの図根点と によって形成されるピラミッドの辺長を図解法により 近似值を求め, 近似計算の繰り返し計算によってその 辺長の精算を行ない, 次いで撮影点の位置の座標値も 近似式の繰り返し計算によって精算し, 最後にカメラ の傾斜角孛計算して外部標定に必要な計算を完了し た。

これらの計算には Hugerschoff-Cranz の導いた式 ${ }^{1}$

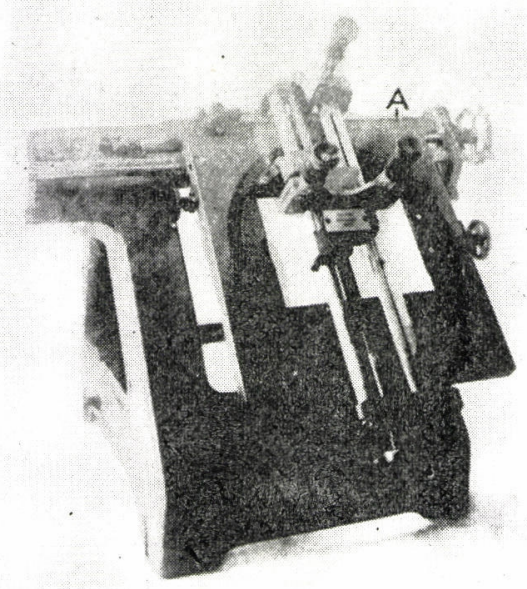

第 4 図座標测定機

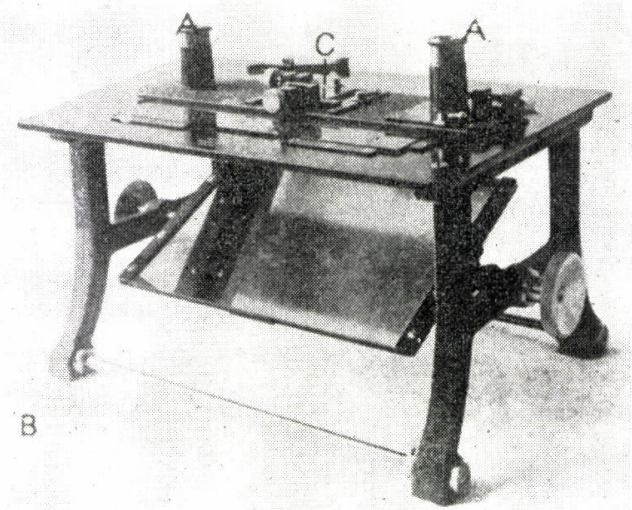

第 5 図標刻機

を有いた。

\section{4. 機械図化亡その結果}

図化機は第 1 節で述べた Hugerschoff $の$ Autocarto$\operatorname{graph}^{(2)}$ 厄, 第 6 図に示す 如 $<$, 焦点距離 $16.5 \mathrm{~m}$ 乾 板の大きさ, $13 \times 18 \mathrm{~cm}^{2}$ の光学的投影機老備之，坐 標系は機械的レパーを平面 困と立面図とに分解して投 影する力式のいわゆる光学 的機械的投影法圭用いた二 般解法の最初の図化機であ る。

試験作業には標定計算で 求めた外部標定諸元を機械 に設定し，1/2,500 の図化 を行なった。第7図にはそ 


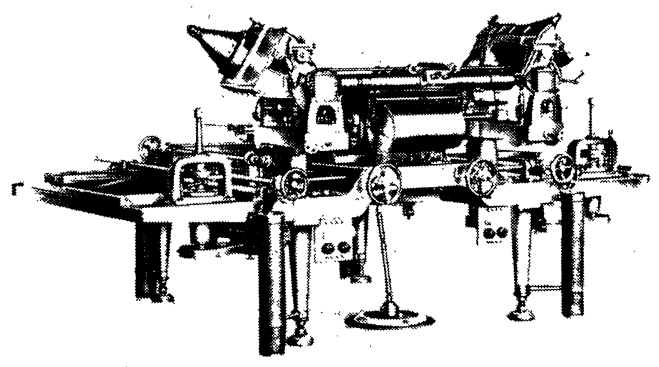

第 6 図 Autocertograph

の一部を示し,これを現地と対照し, 点検した結果, 斜写真のため写真上で明膫でなく判読の誤りたる点も あったがほぼ所望の精度を得ることができた。

経費, 能率, 精度等な扮研究すべき点もあるが, 測 量に応用する見込十分であって，更に飛行機による空 中写真の研究に着手すべきであると結論した。

\section{5. あとがき}

使用した機械は刻点機, 単眼コンパレータ等は今日 再び登場した解析用写真測量機械 (Analytical Photogrammetric lnstrument）であり，また標定計算に用い た条件式や，近似計算の繰り返し計算によって収歛さ 女る方式等は現在われわれが行なっている近代解析法 の基礎をなすものである。

先生は結論として, 飛行機による写真測量へと進む べきであるとして，続いて 1925 年 Stereoplanigraph
C/1による飯能地区の図化を行なわれた。その後実体 曲線描画機による一連の写真测量方式を開発されたの である。

先生は終戦後においでも電子計算機の登場による解 析写真測量の採用されることを冕速く祭知され，1957 年“計算機による航空基点測量”を編され，われわれ 現在実施している近代解析法の基礎を築かれたのであ る。先生のもとで写真測量の一端をになう機会を持つ ことのできた一人として感慨深く，ここに記した次第 である。

な打 Autocartograph は東大農学部に移され，後東 大生研にあって戦災を免がれた。かって Hugerschoff のもとで写真測量の研究をされていた Dr. Brucklacher はこのことを聞いて懐しがっておられた次第で ある。

\section{参考交献}

1) R. Hugcrschoff, H. Cranz: "Grundlagen der Photogrammetrie aus Luftfahrzeugen," 1919

2) R. Hugerschoff: "Photogrammetrie und Luftbildwesen" 1930

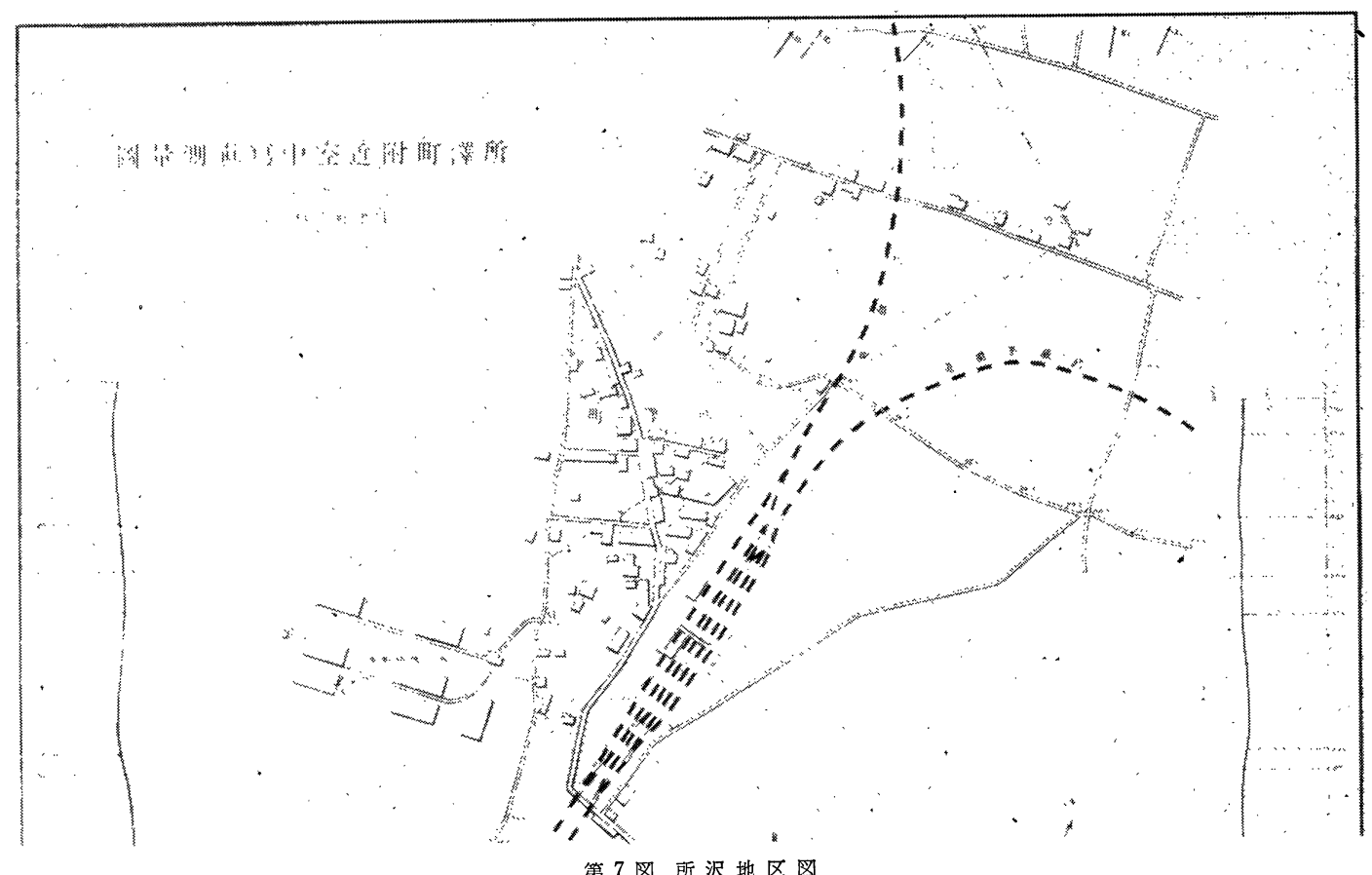

